Article

\title{
Bacterial Cellulose and Emulsified AESO Biocomposites as an Ecological Alternative to Leather
}

\author{
Marta Fernandes ${ }^{1}(0)$, António Pedro Souto ${ }^{1}$, Miguel Gama ${ }^{2, *}$ and Fernando Dourado ${ }^{2}$ \\ 1 2C2T-Centre for Textile Science and Technology, University of Minho, Campus de Azurém, 4800-058 \\ Guimarães, Portugal; marta.fernandes@det.uminho.pt (M.F.); souto@det.uminho.pt (A.P.S.) \\ 2 CEB-Centre of Biological Engineering, University of Minho, Campus de Gualtar, 4710-057 Braga, Portugal; \\ fdourado@deb.uminho.pt \\ * Correspondence: fmgama@deb.uminho.pt; Tel.: +351-253-604-418
}

Received: 31 October 2019; Accepted: 28 November 2019; Published: 29 November 2019

\begin{abstract}
This research investigated the development of bio-based composites comprising bacterial cellulose (BC), as obtained by static culture, and acrylated epoxidized soybean oil (AESO) as an alternative to leather. AESO was first emulsified; polyethylene glycol (PEG), polydimethylsiloxane (PDMS) and perfluorocarbon-based polymers were also added to the AESO emulsion, with the mixtures being diffused into the BC 3D nanofibrillar matrix by an exhaustion process. Scanning electron microscopy (SEM) and Fourier transform infrared (FTIR) spectroscopy analysis demonstrated that the tested polymers penetrated well and uniformly into the bulk of the BC matrix. The obtained composites were hydrophobic and thermally stable up to $200{ }^{\circ} \mathrm{C}$. Regarding their mechanical properties, the addition of different polymers lead to a decrease in the tensile strength and an increase in the elongation at break, overall presenting satisfactory performance as a potential alternative to leather.
\end{abstract}

Keywords: bacterial cellulose; acrylated epoxidized soybean oil; biocomposite; emulsion; exhaustion; alternative leather

\section{Introduction}

The tannery industry faces several challenges associated with high environmental impact, scarcity of raw materials and increasing consumer demand for environmentally friendly products. The worldwide production of leather is approximately 20 billion square feet per year [1]. To produce 1 ton of leather, 6.7 tons of raw skin [2], 57,000 liters of water [3], and 3.35 tons of chemicals are required [4]. Worldwide, for bovine skin, 370 billion liters of water are consumed annually, generating 6.5 million tons of solid waste. This research intends to contribute to the reduction of the animal hide dependency by the development of composites from bacterial cellulose (BC) as structuring material and activated vegetable oils as a flexibilizing, mechanical reinforcing and hydrophobizing agent. $\mathrm{BC}$ is a biopolymer produced by bacterial fermentation that consists exclusively of a three-dimensional structure of pure cellulose nanofibers. Chemically, BC is identical to vegetable cellulose but the nano-scale of its fibers offers a significantly higher surface area [5].

Regarding its application in the textile and footwear sectors, the first proof of concept of the use of BC as an alternative to leather emerged in the 1990s, in the Philippines [6]. In the last decade, the designer Suzanne Lee has expanded the possibility of using BC in the manufacture of clothing and footwear, by resorting to the handmade production of $\mathrm{BC}$, which is washed, adjusted to a predefined form, dried and dyed [7]. Since then, other studies have mainly focused on comfort and appearance, overlooking important properties such as breaking strength, elongation at break or hydrophobicity [8-11]. In our previous work [12], we demonstrated the feasibility of using BC, as 
obtained by static culture, impregnated with two commercial hydrophobic polymers, resulting in a composite with potential textile or leather-like material.

Vegetable oils (VOs) are abundant renewable resources with an increasing number of industrial applications. They offer the advantages of low cost, nontoxicity and biodegradability [13-16]. Basically, these biopolymers are composed of triglycerides. The fatty acids in most common triglycerides vary from 14 to 22 carbons in length and have 0 to 3 double bonds $[15,17,18]$. Among the VOs, soybean oil is one of the most attractive due to its low price and abundant availability. To increase their reactivity, double bonds can be replaced by more reactive functional groups such as epoxide, acrylate, hydroxyl or maleate [16,19-21]. Most commonly, double bonds are epoxidized and then acrylated, reacting with carboxyl groups of acrylic acids, allowing free radical polymerization [21,22]. Acrylated epoxidized soybean oil (AESO) has been studied extensively in the production of composites with high renewable content. Most of these composites include different particles or fibers, such as microcrystalline cellulose [23], regenerated cellulose fibers [24], coconut waste [25], discarded cotton/polyester and denim fabrics [26,27], ramie fibers [28], hemp fibers [17,29,30], flax and glass fibers [17] or pyrolyzed chicken feather fibers [20].

Regarding leather and analogues, AESO was surface-grafted onto goat leather using UV-radiation [31]. A recent patent [3] demonstrated the possibility of manufacturing ecological leather analogues by mixing natural fibers with epoxidized and acrylated triglycerides and vinyl monomers, the mixture being chemically polymerized. The composite was then deposited in suitable molds and hot pressed. In another work [32], an environmentally friendly leather substitute was developed by reinforcing a mixture of AESO resin with cotton fabrics. Later, an ecological leather composed of organic cotton fabrics and AESO/MLAU (methacrylated lauric acid) (50/50) resin was tested in footwear [33]. Although the authors presented this product as water-resistant and breathable, no tests were performed to support these claims.

Composites of BC with modified soybean oil have been reported. Blaker et al. [34] developed highly porous UV curable nanocomposite foams of BC/AESO by the production of water-in-oil emulsions stabilized by BC nano-fibrils previously hydrophobized by acetylation and silylation. In a more recent work [35], other monomers were added to AESO resin and the emulsions were polymerized by free radicals, for the preparation of thermosetting AESO-BC nanocomposite foams. Lee et al. [36] demonstrated the production of macroporous 3D polymers by microwave heating of gas/AESO liquid foams. The addition of $\mathrm{BC}$ allowed a significant improvement of the stability and the mechanical properties. Retegi et al. [37] developed optically transparent composites with excellent mechanical properties when impregnating BC films with epoxidized soybean oil. To improve the dispersion of the nanofibers and the adhesion between the cellulose and the hydrophobic polymer matrix, the BC films were first acetylated.

From the above, as is the purpose of this work, it is expected that by combining never dried BC membranes, as obtained by microbial fermentation, with a biodegradable polymer such as AESO, it may be possible to produce a truly green nanocomposite with potential applications in the leather industry. BC constitutes a three-dimensional polymeric structure with interconnected fibers, with macroporosity and therefore high aptitude to the anchorage of the AESO emulsified particles. Further, using emulsified VOs as low-cost natural substrates obviates the need to surface-modify BC, thus simplifying the preparation of BC-based composites while not affecting the BC's native properties. This strategy represents a novel and promising approach towards the development of an environmentally friendly product, exclusively from biological and recyclable materials, at low water and energy production costs. 


\section{Materials and Methods}

\subsection{Materials}

Bacterial cellulose membranes were offered by Satisfibre S.A. (Braga, Portugal). Soybean oil, epoxidized acrylate (Sigma-Aldrich, Steinheim, Germany), lauryl methacrylate (97\%) (Acros Organics, Geel, Belgium), 1,6-hexanodiol diacrylate (80\%) (Sigma-Aldrich, Steinheim, Germany), tri(propylene glycol) diacrylate (Sigma-Aldrich, Steinheim, Germany), Triton X-100 (Sigma-Aldrich, Steinheim, Germany), Span 80 (Sigma-Aldrich, Steinheim, Germany), isobutanol (Merck Millipore, Darmstadt, Germany), cumene hydroperoxide (80\%) (Sigma-Aldrich, Steinheim, Germany), cobalt naphthenate (6\%) (Sigma-Aldrich, Steinheim, Germany), and polyethylene glycol 400 (Merck Millipore, Darmstadt, Germany), were used as received. Persoftal MS Conc.01 and Baygard EFN (Tanatex Chemicals) were offered by ADI Center (Santo Tirso, Portugal).

\subsection{Methods}

\subsubsection{Preparation of the Acrylated Epoxidized Soybean Oil (AESO) Mixture}

AESO was used in this work to produce a hydrophobic composite with high bio-based content. AESO is synthesized from soybean oil (renewable resource abundantly available) via epoxidation and acryloilation. It contains three highly reactive functionalities, double $(\mathrm{C}=\mathrm{C})$ bonds, $-\mathrm{OH}$ groups, and epoxy rings. The $\mathrm{C}=\mathrm{C}$ bond in AESO is capable of self-polymerizing and copolymerizing with other components via a free-radical initiation, forming a three-dimensional network. However, it has a low crosslinking density and thus inferior mechanical strength due to the existence of long aliphatic chains and low degree of unsaturation in AESO molecules. Also, it has high viscosity at room temperature that restricts its processability [29]. To reduce these limitations, a mixture was prepared by adding different reactive monomers to AESO at room temperature. This mixture was composed of acrylated epoxidized soybean oil $(50 \% \mathrm{~m} / \mathrm{m})$; lauryl methacrylate $(40 \% \mathrm{~m} / \mathrm{m})$-a fatty acid-based reactive diluent, potentially bio-based, which reduces the viscosity of the mixture [38]; 1,6-hexanodiol diacrylate (5\% $\mathrm{m} / \mathrm{m})$; and tri(propylene glycol $\mathrm{m} / \mathrm{m}$ ) diacrylate $(5 \% \mathrm{~m} / \mathrm{m})$-bifunctional monomers which can enhance the crosslinking [39].

2.2.2. Determination of Required the Hydrophilic-Lipophilic Balance (HLB) and AESO Emulsion Stability Evaluation

The Hydrophilic-Lipophilic Balance (HLB) values are generally considered vital for the stabilization of surfactant-based emulsions. Tritons and Spans are a range of non-ionic surfactants stable in mild alkalis, acids and electrolytes and have no reaction with ionic ingredients or actives. To prepare stable AESO emulsions, the effect of HLB was first studied by preparing different combinations of two non-ionic surfactants (Triton X-100 and Span 80) and a co-surfactant (Butanol) in a ratio of 2:1, as presented in Table 1. The HLB values of the mixed surfactants were calculated by Equation (1) [40]:

$$
H L B_{\text {mix }}=\left(H L B_{A} X_{A}\right)+\left(H L B_{B} X_{B}\right)+\left(H L B_{C} X_{C}\right)
$$

where $H L B_{\text {mix }}, H L B_{A}, H L B_{B}$, and $H L B_{C}$ are the HLB values of the mixture, Triton X-100, Span 80, and Butanol, respectively, and $X_{A}, X_{B}$ and $X_{C}$ are the weight percentages of every surfactant in the mixture. HLB values from 5.20 (more lipophilic or oil soluble) up to 11.33 (more hydrophilic or water soluble) were obtained.

The oil-in-water $(\mathrm{O} / \mathrm{W})$ emulsions were prepared with a mass ratio of 20:2:78 (AESO mixture/surfactant combination/water), as follows: $2 \mathrm{~g}$ of the surfactant combination (Table 1) were added to $20 \mathrm{~g}$ of the AESO mixture, followed by the addition of $78 \mathrm{~g}$ of deionized water. The mixture was emulsified using a homogenizer (Unidrive X 1000 D, CAT, Staufen, Germany) at a speed of 30,000 $\mathrm{rpm}$, for 1, 5 and $10 \mathrm{~min}$. This process was carried out in an ice bath to avoid temperature rise during emulsification. After this, the emulsions were stored in test tubes at room temperature to investigate 
their stability over time (up to 10 days) under conditions of varied HLB and stirring time. The stability was evaluated by visually recording signs of phase separation and creaming; the droplet morphology of the emulsions was investigated by optical microscopy using a Leica DM750 M microscope (Leica Microsystems, Wetzlar, Germany) with a Leica MC 170HD camera, using a 10× eyepiece lens and 100× objective lens.

Table 1. Combinations of surfactants used to study the effect of HLB on the AESO emulsion stability.

\begin{tabular}{ccccc}
\hline $\begin{array}{c}\text { Surfactant } \\
\text { Combination }\end{array}$ & $\begin{array}{c}\text { Triton X-100 (\%) } \\
(\text { HLB }=\mathbf{1 3 . 5})^{\mathbf{1}}\end{array}$ & $\begin{array}{c}\text { Span 80 (\%) } \\
(\mathbf{H L B}=\mathbf{4 . 3})^{\mathbf{1}}\end{array}$ & $\begin{array}{c}\text { Butanol (\%) } \\
(\mathbf{H L B}=\mathbf{7 . 0 )} \text { [41] }\end{array}$ & HLB $_{\text {mix }}$ \\
\hline A & 0.00 & 66.67 & 33.33 & 5.20 \\
B & 19.57 & 47.10 & 33.33 & 7.00 \\
C & 41.31 & 25.36 & 33.33 & 9.00 \\
D & 66.67 & 0.00 & 33.33 & 11.33 \\
\hline \multicolumn{5}{c}{}
\end{tabular}

\subsubsection{Exhaustion of BC Membranes with Emulsified AESO}

To test the incorporation of AESO in BC membranes, an emulsion was prepared by adding the initiator cumene hydroperoxide (CHP) $(3 \% \mathrm{~m} / \mathrm{m})$ and the catalyst cobalt naphthenate (CONP) $(0.8 \%$ $\mathrm{m} / \mathrm{m}$ ) to the AESO mixture. This initiator permits the polymerization of AESO at low temperatures [42], which prevents the aggregation or coalescence of the emulsified AESO particles. An emulsion with HLB of 11.3 (Table 1-D), which provided the best results obtained in the storage stability studies, was prepared using the same procedure described in Section 2.2.2.

BC membranes (with about $3.0 \mathrm{~cm}$ in thickness, with a size of $12.0 \times 2.5 \mathrm{~cm}$ and weighting $90 \mathrm{~g}$ ) were each treated by exhaustion with $100 \mathrm{~g}$ of emulsified AESO mixture for 9 days at $40^{\circ} \mathrm{C}$ (Sample 1) followed by a $3 \mathrm{~h}$ curing step at $90{ }^{\circ} \mathrm{C}$ (Sample 2), to accelerate the cross-link of the emulsified AESO mixture. The composites were then dried at $40{ }^{\circ} \mathrm{C}$ in an oven (WTC series, Binder GmbH, Tuttlingen, Germany) for 5 days. To avoid shrinkage of the samples during drying, the composites were attached to a zinc-plated wire support. Regarding the exhaustion process, it was carried out in an Ibelus machine (IL-720, Labelus, Braga, Portugal) equipped with an infrared heating system, using stainless steel cups with a capacity of approximately $220 \mathrm{~cm}^{3}$, with a rotation of $50 \mathrm{rpm}, 40$ cycles, and a temperature gradient of $2{ }^{\circ} \mathrm{C} \cdot \mathrm{min}^{-1}$. Samples were collected after the exhaustion process and before drying, for analysis by scanning electron cryomicroscopy (described below).

\subsubsection{Production of Composites with Different Polymers}

Several composites were also produced by adding other polymers to the pre-emulsified AESO mixture. These were PEG 400, Persoftal MS Conc.01 (PDMS-based softener (S)) and Baygard EFN (perfluoroarbon-based hydrophobizer $(\mathrm{H})$ ). Softeners (Persoftal) and hydrophobizers (Baygard) used in the textile industry are usually liquid dispersions or emulsions that, in addition to active agents (polysiloxanes or fluorocarbons), contain emulsifiers (e.g., ethoxylated fatty alcohols), dispersants, defoamers. Details on the characteristics of Persoftal and Baygard were presented in our previous work [12]. PEG is a polymer with functionalities such as steric stabilization, which can be used to prevent particle agglomeration [43]; it is a nonionic surfactant able to form long chain structures in aqueous solution; it is also a plasticizer agent with the ability to increase molecular spacing, thus offering flexibility [44].

To produce the composites, $\mathrm{BC}$ membranes (with about $3.0 \mathrm{~cm}$ in thickness, with a size of $12.0 \times$ $13.0 \mathrm{~cm}$ and weighting $450 \mathrm{~g}$ ) were first squeezed to a final wet mass of $100 \mathrm{~g}$. Then the compressed membranes were each treated by exhaustion with $100 \mathrm{~g}$ of an aqueous mixture as shown in Table 2, adding water to complete the $100 \mathrm{~g}$. 
Table 2. Proportions of the polymers in the aqueous mixture used in the production of BC composites.

\begin{tabular}{ccccc}
\hline Sample & $\begin{array}{c}\text { AESO Emulsion } \\
(\mathbf{g})\end{array}$ & PEG $\mathbf{4 0 0}$ (g) & Persoftal MS (g) & Baygard EFN (g) \\
\hline BC/AESO & 75 & - & - & - \\
BC/AESO/PEG & 75 & 4.5 & - & - \\
BC/AESO/S & 75 & - & 18 & - \\
BC/AESO/PEG/S & 75 & 4.5 & 18 & - \\
BC/AESO/H & 75 & - & - & 18 \\
BC/AESO/PEG/H & 75 & 4.5 & - & 9 \\
BC/AESO/PEG/S/H & 75 & 4.5 & 9 & \\
\hline
\end{tabular}

For the preparation of these mixtures, the AESO mixture emulsion was first prepared as described on Sections 2.2.2 and 2.2.3. Then PEG, Persoftal or Baygard were added and the mixture was stirred at $500 \mathrm{rpm}$ for $1 \mathrm{~min}$.

The exhaustion treatment lasted for 5 days at $30^{\circ} \mathrm{C}$, in the same equipment above described, after which the samples were oven dried for 5 days at $40^{\circ} \mathrm{C}$, followed by a curing step for $3 \mathrm{~h}$ at $90^{\circ} \mathrm{C}$. As before, to avoid shrinkage of the samples during drying and curing, the composites were attached to a zinc-plated wire support.

The polymer content in the final composites was calculated through the Equation (2):

$$
\text { Polymer Content }=\left(\frac{W_{\text {composite }}-W_{B C}}{W_{\text {composite }}}\right) \times 100
$$

where $W_{\text {composite }}$ corresponds to the dry mass of the composite, and $W_{B C}$ corresponds to the dry mass of BC.

\subsubsection{Characterization of the BC-Based Composites}

Scanning Electron Cryomicroscopy (Cryo-SEM)

SEM analyses of the $\mathrm{BC}$ and $\mathrm{BC}$ composites were performed using a high-resolution Scanning Electron Microscope (JEOL JSM 6301F, JEOL, Tokyo, Japan) with X-ray Microanalysis (Oxford INCA Energy 350, Oxford Instruments, Abingdon, England) and a CryoSEM (Gatan Alto 2500, Gatan, Pleasanton, CA, USA). The non-dried specimens were rapidly cooled (plunging it into sub-cooled nitrogen-slush nitrogen) and transferred under a vacuum to the cold stage of the preparation chamber. Then the samples were fractured, sublimated ('etched') for $120 \mathrm{~s}$ at $-90^{\circ} \mathrm{C}$, and coated with $\mathrm{Au} / \mathrm{Pd}$ by sputtering for 45 seconds with a $12 \mathrm{~mA}$ current. Afterward, the samples were transferred into the SEM chamber and analyzed at a temperature of $-150{ }^{\circ} \mathrm{C}$.

\section{Scanning Electron Microscopy (SEM)}

Analyses of the surface and cross-section morphology of the dried BC and BC composites were done using an ultra-high-resolution field emission gun SEM instrument (NOVA 200 Nano SEM, FEI Co. Hillsboro, OR, USA). To analyze the cross-section, the samples were first freeze-fractured with liquid nitrogen and coated with a thin layer of $\mathrm{Au} / \mathrm{Pd}$.

Fourier Transform InfraRed (FT-IR) Spectroscopy

A Nicolet Avatar 360 FT-IR spectrophotometer (Madison, WI, USA) was used to record the FT-IR spectra of the dried BC sheet and BC composites. The spectra were collected in the attenuated total reflection mode (ATR) at a spectral resolution of $16 \mathrm{~cm}^{-1}$, with 60 scans, over the range $650-4000 \mathrm{~cm}^{-1}$ at room temperature. A background scan with no sample and no pressure was acquired before the spectra of the samples were collected. 
Contact Angle (CA) and Surface Free Energy (SFE)

The surface wettability was accessed by contact angle measurements carried out in a DataPhysics instrument (Filderstadt, Germany) with a video system for the capture of images every $0.04 \mathrm{~s}$ in static mode using the sessile drop method, using OCA20 software (version 1.5, Dataphysics instrument, Filderstadt, Germany). A drop of $5 \mu \mathrm{L}$ of distilled water was placed on the dried composite's surface with a microliter syringe and observed with a special charge-coupled device camera. Afterward, the water contact angle was observed over time for $180 \mathrm{~s}$. At least five measurements at different places were taken for each sample. To calculate the surface energy $\left(\gamma_{s}\right)$ of the BC composites and their polar $\left(\gamma_{s}^{P}\right)$ and dispersive $\left(\gamma_{s}^{D}\right)$ components, the Wu method (harmonic-mean) was used, with Equation (3) [45]:

$$
\gamma_{s l}=\gamma_{s}+\gamma_{l}-4\left(\frac{\gamma_{s}^{D} \gamma_{l}^{D}}{\gamma_{s}^{D}+\gamma_{l}^{D}}+\frac{\gamma_{s}^{P} \gamma_{l}^{P}}{\gamma_{s}^{P}+\gamma_{l}^{P}}\right)
$$

The following liquids with known surface energy and surface energy components were used: distilled water $\left(\gamma: 72.8 ; \gamma^{D}: 29.1 ; \gamma^{P}: 43.7\right)$; polyethylene glycol $200\left(\gamma: 43.5 ; \gamma^{D}: 29.9 ; \gamma^{P}: 13.6\right)$; and glycerol $\left(\gamma: 63.4 ; \gamma^{D}: 37.4 ; \gamma^{P}: 26.0\right)$, units in $\mathrm{mJ} \cdot \mathrm{m}^{-2}[46]$.

Differential Scanning Calorimetry (DSC)

DSC curves were obtained on a Mettler-Toledo DSC822 instrument (Giessen, Germany). Samples weighing about 5-7 mg (the exact mass was recorded before each assay) were heated in hermetically-sealed aluminum pans and tested in the temperature range of 25 to $450{ }^{\circ} \mathrm{C}$ at a heating rate of $10^{\circ} \mathrm{C} \cdot \mathrm{min}^{-1}$, under inert nitrogen atmosphere at $80 \mathrm{~mL} \cdot \mathrm{min}^{-1}$ flow rate.

ThermoGravimetric Analysis (TGA)

Thermogravimetric analysis was carried out in a Hitachi STA7200 (Tokyo, Japan). Samples weighing 5-7 mg (the exact mass was recorded before each assay) were placed in platinum pans and tested from 25 to $600{ }^{\circ} \mathrm{C}$ at a heating rate of $10{ }^{\circ} \mathrm{C} \cdot \mathrm{min}^{-1}$ under a nitrogen flow rate of $200 \mathrm{~mL} \cdot \mathrm{min}^{-1}$.

Mechanical Properties

Tensile strength and elongation at break measurements were evaluated according to the standard ISO 17706:2003 [47]. The overall width of the sample $(25 \mathrm{~mm})$ was fixed and a length that allows an initial distance between the clamps of the tester equipment (Hounsfield HSK100, Salfords, UK) of 75 $\mathrm{mm}$ was set out in grips and subjected to tensile and tear. Three samples of each dried material were tested at a constant speed of $100 \mathrm{~mm} \cdot \mathrm{min}^{-1}$.

\section{Results and Discussion}

\subsection{Emulsions Stability and Diffusion into BC}

Both the HLB value of the surfactant mixture (Triton-X100/Span 80/Butanol) and emulsification time had a significant effect on the stability of the $\mathrm{O} / \mathrm{W}$ emulsions, as evaluated by visual observation over 10 days. As shown in Figure 1b, at HLB of 5.20, the lowest creaming formation was observed in emulsions prepared with longer mixing times. Increasing the HLB value to 11.33, hence increasing the hydrophilic ratio of the surfactant's mixture, allowed for the stabilization of the emulsion for up to 10 days (Figure 1f), regardless of the emulsification time, as no creaming was observed after 10 days of storage. 

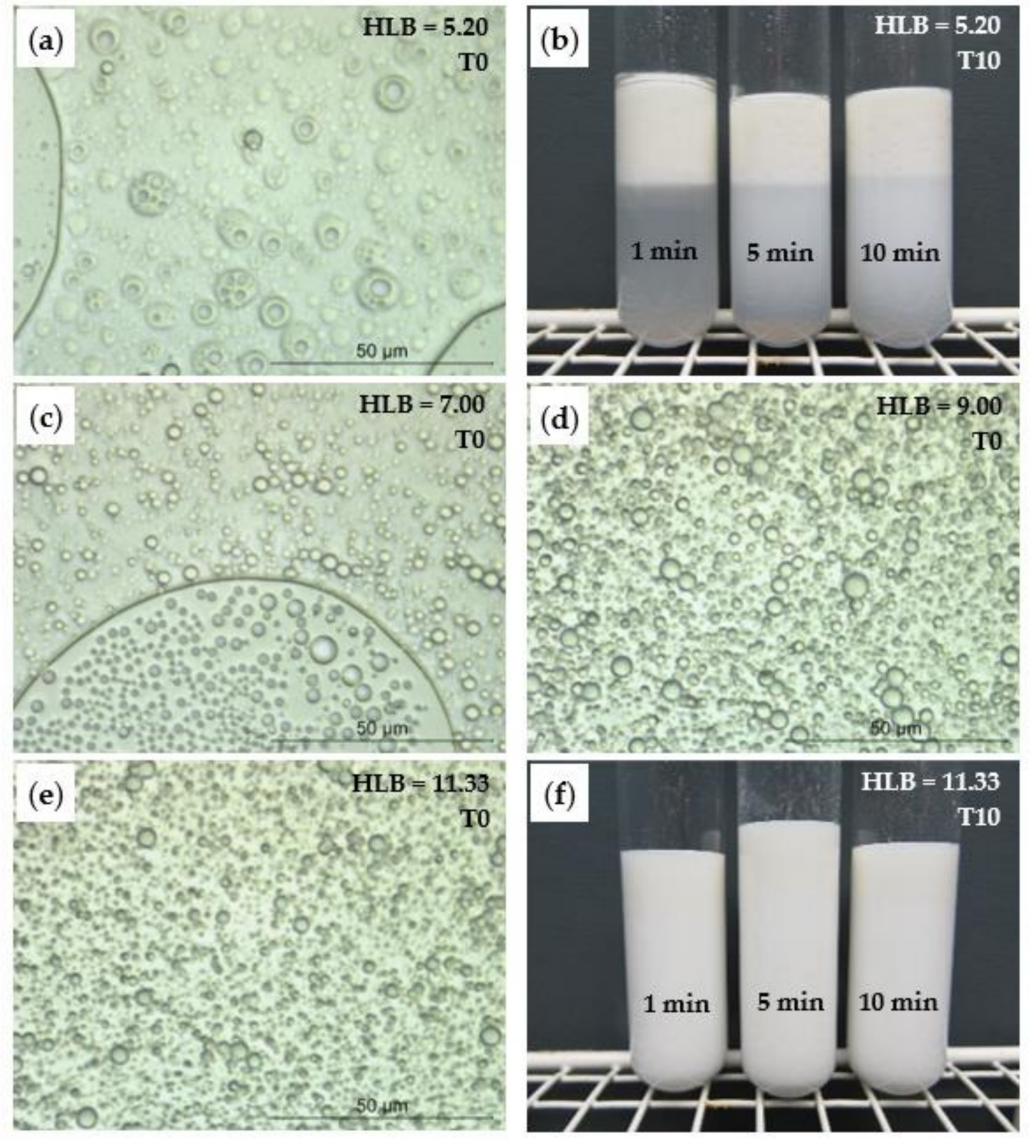

Figure 1. Optical micrographs (100× magnification) of freshly prepared AESO emulsions with different HLB and after 10 min of emulsification: (a) HLB 5.20, (c) HLB 7.00, (d) HLB 9.00, and (e) HLB 11.33; and visual appearance of AESO emulsions at different times of emulsification after 10 days storage: (b) HLB 5.20 and (f) HLB 11.33 .

The optical microscopy images of the emulsions prepared with different HLB values were taken immediately following preparation. At lower HLB (Figure 1a,c), emulsions exhibit larger droplet size (possibly containing also some multivesicular droplets, Figure 1a) and size variability, as opposed to those with higher HLB. Thus, a surfactants mixture with HLB 11.33 and $10 \mathrm{~min}$ of emulsification was selected for further work.

After determining the best HLB value for the preparation of the AESO emulsions, impregnation of $\mathrm{BC}$ was done through the exhaustion process. This process commonly used in textile technology involves placing the fabric or yarn in a chamber containing water and treatment products. The chamber is then sealed and the treatment solution heated and submitted to heavy stirring, which results in the products transitioning from the water to the fabric or yarn. This procedure was adopted in this work to process the $\mathrm{BC}$ membranes, incorporating the AESO emulsion into the cellulosic porous network. Although several authors addressed the development of composites using BC fibers, very few papers use the intact membranes obtained by static fermentation, as it is demonstrated in this work. To confirm the presence of AESO particles inside the BC 3D nanofibrillar matrix, the composite samples were examined by Cryo-SEM. Figure 2 shows the 3D porous fiber network structure of BC (Figure 2a) and of the AESO particles adsorbed onto the surface of the nanofibers (Figure $2 \mathrm{~b}$ ), after 9 days at $40{ }^{\circ} \mathrm{C}$, showing no signs of particle aggregation or coalescence. However, by increasing the temperature to $90{ }^{\circ} \mathrm{C}$ for $3 \mathrm{~h}$, during the exhaustion process (Figure 2c), the coalescence of the AESO particles was observed, possibly due to the emulsion breakdown at a higher temperature and to lower viscosity, associated with an incomplete polymerization. Figure $2 \mathrm{~d}$ shows a SEM micrograph of the dried $\mathrm{BC} / \mathrm{AESO}$ composite at a higher magnification. The collapse of the $\mathrm{BC}$ porous structure is observed 
upon drying, producing a structure with packed AESO particles. Further work was performed by drying the material at $40{ }^{\circ} \mathrm{C}$ before post curing at $90^{\circ} \mathrm{C}$, attempting to control the coalescence to some extent.
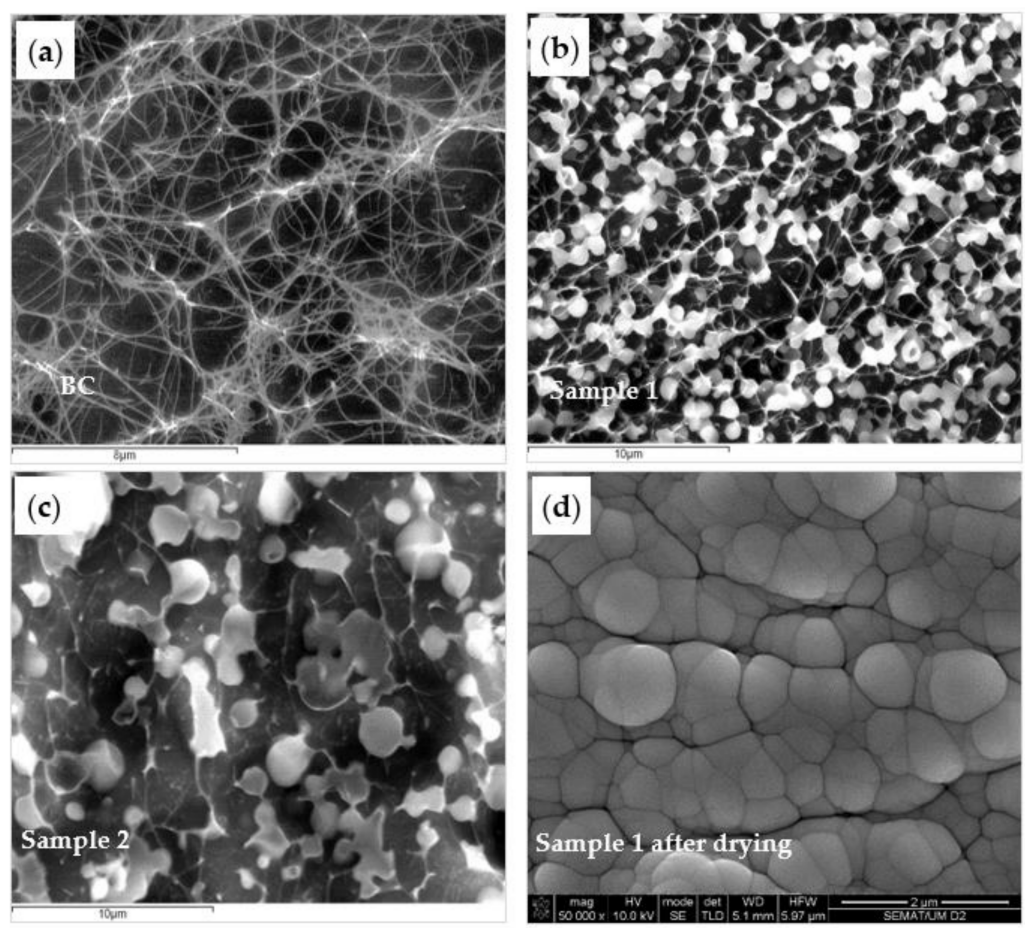

Figure 2. CryoSEM images: (a) BC membrane, (b) after exhaustion with $\mathrm{AESO}$ emulsion for 9 days at $40{ }^{\circ} \mathrm{C}$ (Sample 1), (c) after exhaustion with AESO emulsion for 9 days at $40{ }^{\circ} \mathrm{C}+3 \mathrm{~h}$ at $90{ }^{\circ} \mathrm{C}$ (Sample 2); and (c) SEM image of the Sample 1 after drying at $40^{\circ} \mathrm{C}$.

\subsection{Morphological Analysis}

BC-based composites were also obtained through exhaustion with AESO emulsion combined with other polymers. The morphological properties of the dried BC and BC-based composites were evaluated by SEM (Figure 3). As expected, the surface and cross-section of dried BC (Figure 3a,e) presented a compacted structure of nanofibers, due to the replacement of cellulose-water-cellulose by cellulose-cellulose hydrogen bonding, the nanofibers being randomly arranged in layers with pores on the surface and throughout the BC matrix [48]. The cross-section SEM analysis of the dried BC composites (Figure 3f-l) confirmed a good bulk penetration of the emulsified polymers during the exhaustion process, coating the BC nanofibers and promoting a more compact and bulky structure, as compared to native BC. SEM images of the surface of the BC composites (Figure 3b-d) show that the polymers also covered the membrane's surface, resulting in a rougher structure where the nanofibers are not distinguished. While sphere-like particles can be observed in cross-section images, the possibility of particle coalescence during drying cannot be excluded. Despite the complete coverage of the fibers by the polymers, the characteristic stratified BC structure is still observed in some cases (ex. BC/AESO: Figure 3f, and BC/AESO/PEG/H: Figure 3h).

As compared to $\mathrm{BC}$, the composites presented an increase in thickness and in the mass per unit area, due to the incorporation of the polymers (Table 3), which varied with the formulation. As compared to BC impregnated with AESO mixture, both the added softener ( $S$, Persoftal) and hydrophobizer (H, Baygard) presented lower impregnation. However, the opposite effect is observed adding PEG to either S, H or both mixtures, suggesting that PEG promoted a higher BC impregnation content. In the case of the mixtures of AESO, $\mathrm{S}$ and/or $\mathrm{H}$, it is not possible to determine whether these were incorporated into $\mathrm{BC}$ in the same proportions as that of the emulsified AESO. 

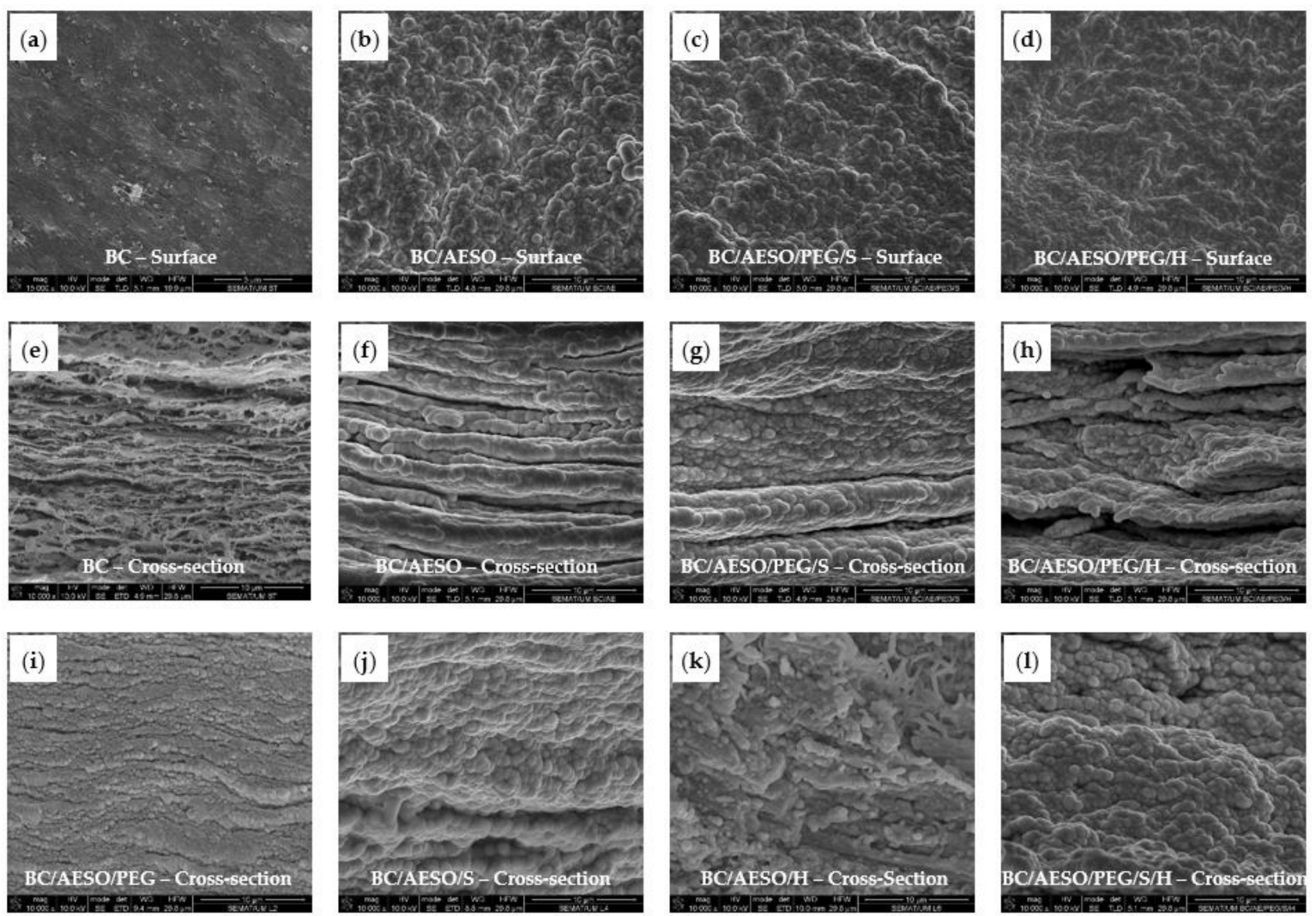

Figure 3. SEM images of $\mathrm{BC}$ and $\mathrm{BC}$ composites: surface and cross-section images, $(\mathbf{a}, \mathbf{e}) \mathrm{BC} ;(\mathbf{b}, \mathbf{f})$ BC/AESO; (c,g) BC/AESO/PEG/S; (d,h) BC/AESO/PEG/H; and cross-section images (i) BC/AESO/PEG, (j) BC/AESO/S, (k) BC/AESO/H, and (1) BC/AESO/PEG/S/H. Magnification: 15,000× (scale: $5 \mu \mathrm{m}$ ) (a) and $10,000 \times($ scale: $10 \mu \mathrm{m})(\mathrm{b}-\mathbf{l})$.

Table 3. Thickness, mass per unit area and polymer content of the composites.

\begin{tabular}{cccc}
\hline Sample & Thickness $(\mathbf{m m})$ & $\begin{array}{c}\text { Mass Per Unit Area } \\
\left(\mathbf{g} \cdot \mathbf{m}^{-\mathbf{2}}\right)\end{array}$ & Polymers Content (\%) \\
\hline BC & 0.48 & 238.0 & - \\
BC/AESO & 0.78 & 686.4 & 65.3 \\
BC/AESO/PEG & 0.55 & 576.0 & 58.7 \\
BC/AESO/S & 0.51 & 552.0 & 56.9 \\
BC/AESO/PEG/S & 0.79 & 921.6 & 74.2 \\
BC/AESO/H & 0.48 & 478.4 & 50.3 \\
BC/AESO/PEG/H & 0.72 & 886.4 & 73.1 \\
BC/AESO/PEG/S/H & 0.95 & 1032.5 & 76.9 \\
\hline
\end{tabular}

\subsection{FTIR Analysis}

Fourier transform infrared (FTIR) spectroscopy was used to characterize the functional groups on the dried BC and BC composites' surfaces (Figure 4). BC spectrum exhibited the characteristic cellulose vibration peaks, namely, $-\mathrm{OH}$ stretching peak at $3344 \mathrm{~cm}^{-1}, \mathrm{C}-\mathrm{H}$ stretching at $2919 \mathrm{~cm}^{-1},-\mathrm{OH}$ bending at $1650 \mathrm{~cm}^{-1},-\mathrm{CH}_{2}$ - bending at $1426 \mathrm{~cm}^{-1}, \mathrm{C}-\mathrm{O}-\mathrm{C}$ deformation modes and stretching vibrations at $1159-1107 \mathrm{~cm}^{-1}, \mathrm{C}-\mathrm{O}-\mathrm{C}$ and $\mathrm{C}-\mathrm{OH}$ stretching vibration of the sugar ring at $1054-1029 \mathrm{~cm}^{-1}$, and $\mathrm{C}-\mathrm{OH}$ out-of-plane bending mode at $665 \mathrm{~cm}^{-1}$ [49-51]. 


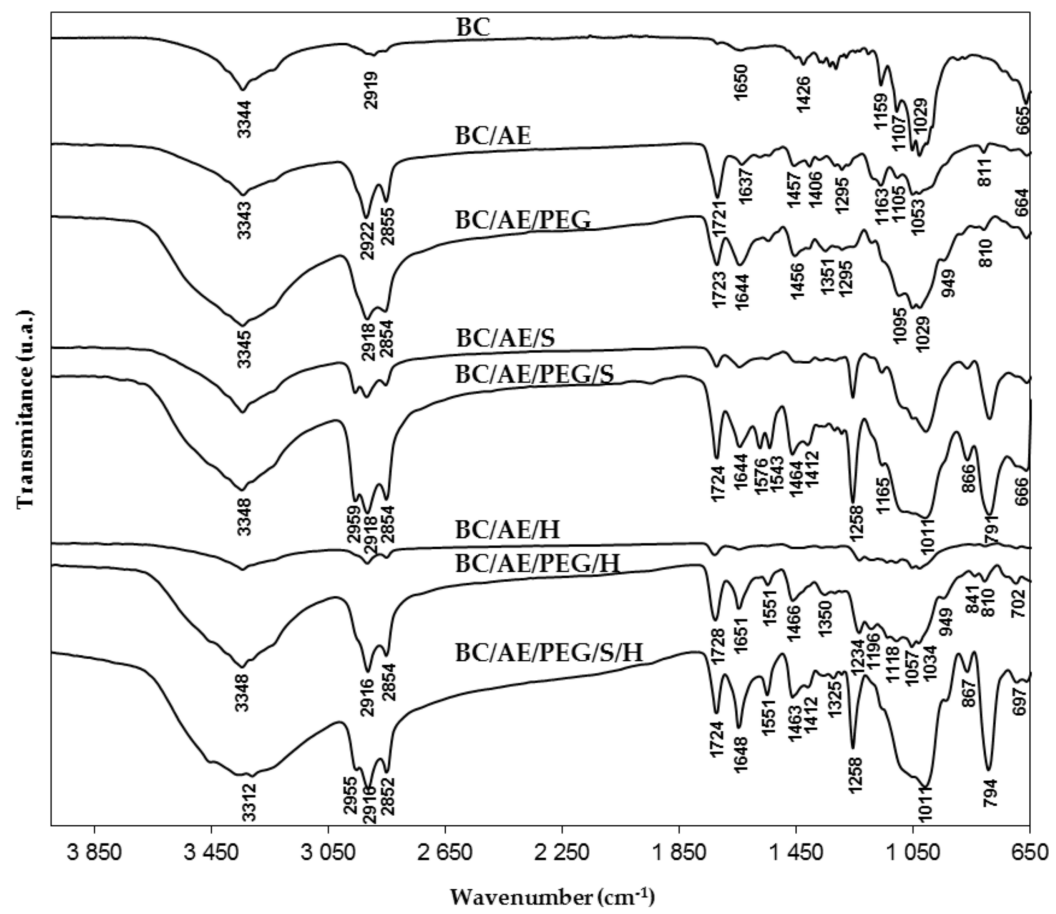

Figure 4. FTIR spectra of BC and the composites.

The spectrum of the BC/AESO composite showed a peak at $3343 \mathrm{~cm}^{-1}$ corresponding to the stretching vibrations of $-\mathrm{OH}$ groups. The peaks at $2922-2855 \mathrm{~cm}^{-1}$ and at $1457-1406 \mathrm{~cm}^{-1}$ are attributed to the asymmetric stretching vibrations and deformation of $\mathrm{C}-\mathrm{H}$ in the $-\mathrm{CH}_{2}-$ and $-\mathrm{CH}_{3}$ bonds, respectively, assigned to the inherent aliphatic sequences of AESO. Another significant peak at $1721 \mathrm{~cm}^{-1}$ is attributed to the stretching vibration of $\mathrm{C}=\mathrm{O}$ in esters and the one at $1637 \mathrm{~cm}^{-1}$ is ascribed to the double-bond signals of acrylate functionalities $\left(-\mathrm{CH}=\mathrm{CH}_{2}\right)$. The peaks at $1295 \mathrm{~cm}^{-1}$ and $1163-1053 \mathrm{~cm}^{-1}$ correspond to $\mathrm{C}-\mathrm{O}$ groups and $\mathrm{C}-\mathrm{O}-\mathrm{C}$ stretching vibration of ester, respectively. Finally, the peak at $811 \mathrm{~cm}^{-1}$ corresponds to the bending vibration of $=\mathrm{C}-\mathrm{H}$, the double bonds on AESO characteristic of the epoxide group $[23,52,53]$.

In the BC/AESO/PEG composite, the increase of some absorption bands can be attributed to PEG400, although they overlap with signals from cellulose and AESO mixture. These bands are located at $3345 \mathrm{~cm}^{-1}$ (-OH stretching), $2918-2854 \mathrm{~cm}^{-1}\left(\mathrm{CH}_{2}\right.$ stretching), $1644 \mathrm{~cm}^{-1}$ (-OH bending), $1456 \mathrm{~cm}^{-1}$ (asymmetric $\mathrm{CH}_{2}$ deformation), $1351 \mathrm{~cm}^{-1}\left(\mathrm{CH}_{2}\right.$ wagging), $1095-1029 \mathrm{~cm}^{-1}\left(\mathrm{CH}_{2}\right.$ symmetric deformation, $\mathrm{C}-\mathrm{O}-\mathrm{C}$ and $\mathrm{C}-\mathrm{OH}$ stretching), $950 \mathrm{~cm}^{-1}\left(\mathrm{CH}_{2}\right.$ rocking), and $664 \mathrm{~cm}^{-1}$ (C-OH out-of-plane bending) $[43,54]$.

In the composite BC/AESO/S, the appearance of new peaks was observed, namely, at $1258 \mathrm{~cm}^{-1}$ $\left(\mathrm{CH}\right.$ vibration in $\left.\mathrm{Si}-\mathrm{CH}_{3}\right)$ and at $791 \mathrm{~cm}^{-1}\left(\mathrm{NH}_{2}\right.$ and $\left.\mathrm{Si}-\mathrm{CH}_{3}\right)$, confirming the incorporation of modified amino-PDMS into the BC composite [55-57]. When PEG 400 was used in the polymer mixture, it was also observed at the peak at $1575 \mathrm{~cm}^{-1}$ that is attributed to the vibration modes of $\mathrm{NH}_{2}$ groups [58]. The vibration bands of Si-O-C and $\mathrm{Si}-\mathrm{O}-\mathrm{Si}$ bridges at around $1165-1011 \mathrm{~cm}^{-1}$ are difficult to analyze as they overlap with the $\mathrm{C}-\mathrm{O}-\mathrm{C}$ vibrations from $\mathrm{BC}$ and PEG $[59,60]$.

In the composites with perfluorcarbon (for BC/AESO/PEG/H), it was possible to identify the bands associated with $\mathrm{CF}_{2}$ groups (asymmetric and symmetric $\mathrm{CF}_{2}$ stretching at 1234 and $1141 \mathrm{~cm}^{-1}$ respectively and 'amorphous' $\mathrm{CF}_{2}$ deformations at $702 \mathrm{~cm}^{-1}$ ) [61]. While in the composite $\mathrm{BC} / \mathrm{AESO} / \mathrm{PEG} / \mathrm{S} / \mathrm{H}$, perfluorocarbon peaks are difficult to identify as they overlap with the characteristic peaks of the PDMS-based polymer. 


\subsection{Surface Wettability and Surface Free Energy}

The $\mathrm{BC}$ composites are designed for leather (textile and footwear) applications; therefore, it is important to determine their surface hydrophobicity. The wetting properties of the BC and BC-based composites were investigated by measuring the water contact angles (WCAs). The obtained values are shown in Figure 5a,b. BC has a highly hydrophilic surface, bearing the lowest water droplet angle $\left(63.1^{\circ}\right)$, which increased for the $\mathrm{BC}$ composites to values between $79.0^{\circ}$ and $138.0^{\circ}$, indicating a significant increase in hydrophobicity. Values of $95.8^{\circ}$ and $79.0^{\circ}$ were observed for BC/AESO and BC/AESO/PEG, respectively. AESO contains hydrophobic long-chain non-polar fatty acid chains [62] and consequently improves the water resistance of the composite. Despite being more hydrophobic, the WCAs over time decreased quickly in these composites, as compared to BC. This can be explained by the closed packed structure of the dried BC that limits the water diffusion through the tight space between the nanofibers, due to the strong and high number of cellulose-cellulose hydrogen bonds [50]. As expected, the incorporation of PDMS (S) and perfluorocarbon-based $(\mathrm{H})$ polymers into BC also significantly increased the WCAs. Both polymers have very low surface tension, $19.5-23.6 \mathrm{mN} \cdot \mathrm{m}^{-1}[63,64]$ and 6-18 $\mathrm{mN} \cdot \mathrm{m}^{-1}$ [65], respectively, thus decreasing the free energy of the system and reducing the surface wettability. However, in the samples with PEG, this increase was not as substantial, since PEG can interact with the $\mathrm{BC}$ membrane by hydrogen bonds. As stated by Kondo et al. [66], the ether oxygen in the poly(ethylene oxide) skeleton forms hydrogen bonds with the primary $\mathrm{OH}$ group at the $\mathrm{C} 6$ position of the anhydroglucose unit. Promising results were observed with all H-composites: higher contact angles (Figure $5 b$ ) and very low absorption rate over time (Figure 5a). The increase in hydrophobicity resulted from a decrease in the polar component of the surface tension and consequently in the total surface free energy of the composite, as shown in Figure 5b. An exception to this trend was observed for $\mathrm{BC} / \mathrm{AESO} / \mathrm{PEG}$, where an increase in the surface free energy was recorded. Among the different polymers tested, AESO was the one that offered less hydrophobicity, and the incorporation of the PEG, being hydrophilic as observed above, increased the value of the polar component.
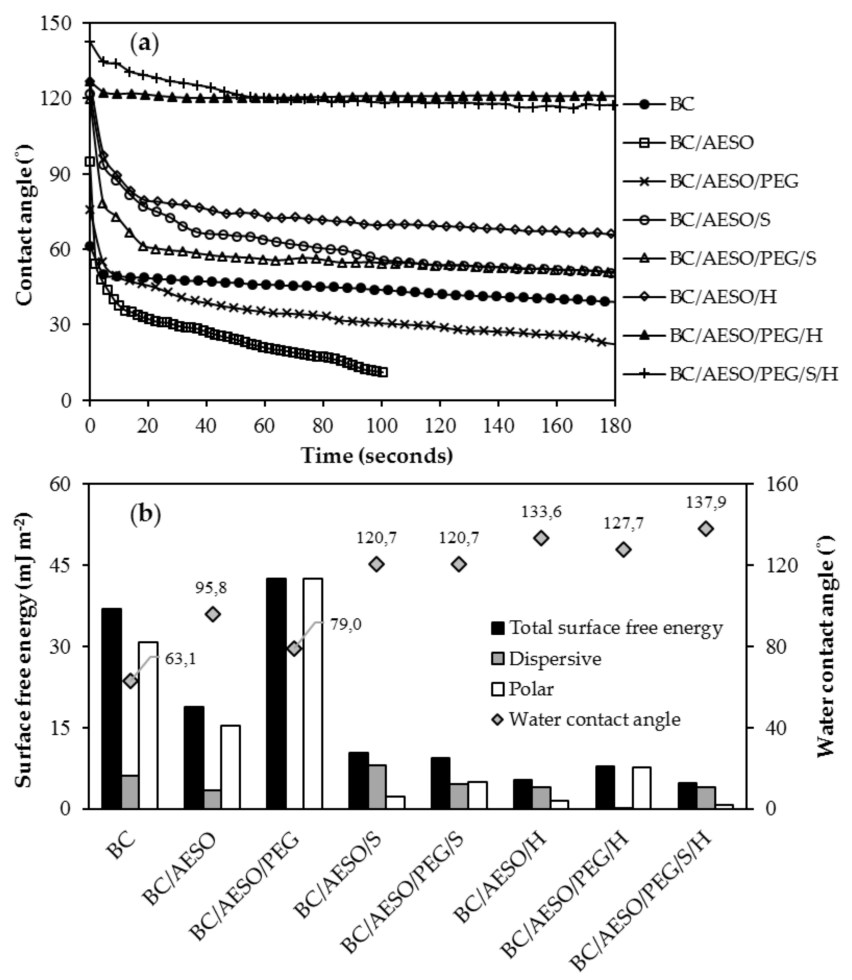

Figure 5. (a) Water contact angle over time and (b) surface free energy. 


\subsection{Thermal Properties}

The thermal properties were evaluated by differential scanning calorimetry (DSC) and thermogravimetric analysis (TGA). DSC and TGA curves of BC and its composites obtained under nitrogen atmosphere are depicted in Figure 6a,b, respectively, and the corresponding relevant data are summarized in Table 4.
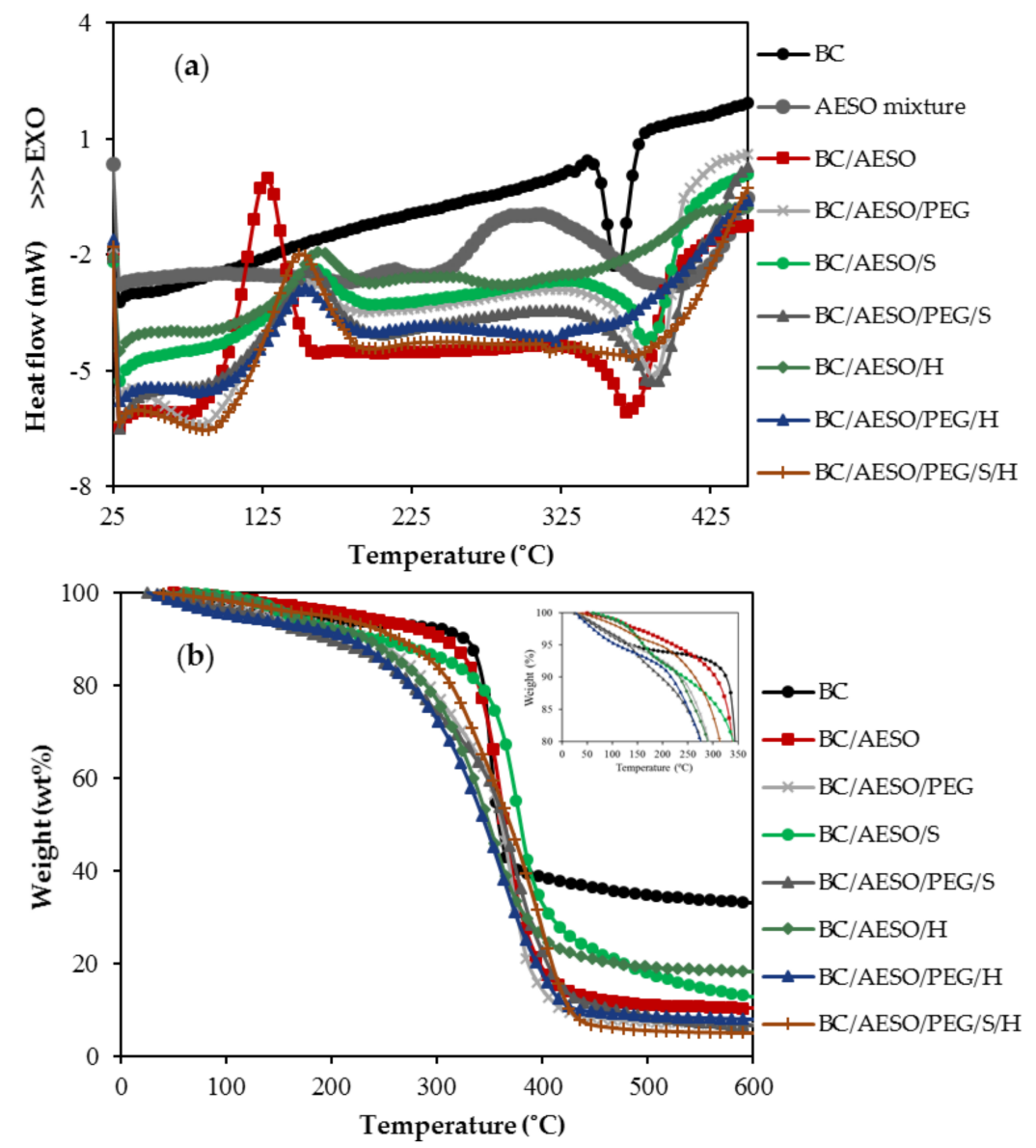

Figure 6. (a) DSC thermograms and (b) TGA curves of weight percentage of dried BC and BC composites.

Table 4. Thermal degradation data obtained from DSC, TGA and DTG curves of dried BC and BC composites.

\begin{tabular}{cccccc}
\hline Sample & $\mathbf{T}_{\mathbf{c}}\left({ }^{\circ} \mathbf{C}\right)^{\mathbf{a}}$ & $\mathbf{T}_{\mathbf{m}}\left({ }^{\circ} \mathbf{C}\right)^{\mathbf{b}}$ & $\mathbf{T}_{\mathbf{5} \mathbf{w t} \%}{ }^{\mathbf{a}}\left({ }^{\circ} \mathbf{C}\right)^{\mathbf{c}}$ & $\mathbf{T}_{\mathbf{1 0} \mathbf{w t} \%}{ }^{\mathbf{b}}\left({ }^{\circ} \mathbf{C}\right)^{\mathbf{d}}$ & $\mathbf{T}_{\mathbf{d m a x}}{ }^{\mathbf{d}}\left({ }^{\circ} \mathbf{C}\right)$ \\
\hline BC & - & 362.2 & 136.1 & 326.4 & 351.0 \\
BC/AESO & 127.3 & 365.0 & 221.9 & 305.0 & 364.4 \\
BC/AESO/PEG & 153.2 & 387.2 & 136.8 & 236.8 & 372.7 \\
BC/AESO/S & 158.1 & 387.6 & 161.9 & 242.9 & 375.9 \\
BC/AESO/PEG/S & 157.3 & 389.9 & 132.5 & 196.9 & 374.3 \\
BC/AESO/H & 161.8 & 350.2 & 161.4 & 232.9 & 353.1 \\
BC/AESO/PEG/H & 151.9 & 365.5 & 109.5 & 217.4 & 361.9 \\
BC/AESO/PEG/S/H & 150.1 & 388.4 & 192.4 & 263.8 & $333.8 / 400.8$ \\
\hline
\end{tabular}

${ }^{a}$ Temperature of the curing exotherm maximum; ${ }^{b}$ Temperature of the degradation endothermal maximum; ${ }^{\mathrm{c}}$ Temperature at $5 \%$ mass loss; ${ }^{\mathrm{d}}$ Temperature at $10 \%$ mass loss; and, ${ }^{\mathrm{e}}$ Temperature(s) at the maximum mass loss rate.

The DSC curve of BC reveals an endothermal degradation peak $\left(\mathrm{T}_{\mathrm{m}}\right)$ at $362.2{ }^{\circ} \mathrm{C}$, which is attributed to partial pyrolysis with the fragmentation of carbonyl and carboxylic bonds from anhydrous glucose units [67]. $\mathrm{BC}$ also shows a narrow weight loss at $351.0^{\circ} \mathrm{C}\left(\mathrm{T}_{\mathrm{dmax}}\right)$, indicating fast degradation, 
involving dehydration, depolymerization of the main polymer network and the decomposition of glucosyl units followed by the formation of a charred residue $[68,69]$.

In the case of the composites, an additional endothermic transition below $100{ }^{\circ} \mathrm{C}$ is observed in the DSC curves, it corresponds to the first step of weight loss in the temperature range of $30-150{ }^{\circ} \mathrm{C}$ observed in Figure $6 b$, which is ascribed to the loss of absorbed water. From Table 4, it is possible to observe that the composites with PEG 400 lost $5 \%$ of their mass at lower temperatures; this occurs because low-molecular polyethylene glycol contributes to higher hygroscopicity, the water being released by evaporation. These samples also present less charred residue, when compared with the composites without PEG. For most of the composites, a second event, in the range of $100-250{ }^{\circ} \mathrm{C}$, is observed before the main degradation. This degradation stage can be considered the evaporation and decomposition of unreacted monomers, catalysts, or other low molecular weight components in the composites [22,70-72].

All DSC curves of the composites display exothermic transitions up to $200{ }^{\circ} \mathrm{C}$, which we hypothesize to correspond to the polymerization of unreacted AESO [73]. A redox initiator system (the initiator cumene hydroperoxide (CHP) and the promoter cobalt naphthenate (CONP)) was used to polymerize AESO during the exhaustion process. This was performed at a relatively low temperature $\left(30^{\circ} \mathrm{C}\right)$, as described by other authors [42], attempting to avoid coalescence of the emulsified AESO (which is favored at a higher temperature due to the reduction of viscosity). However, as stated by Dweib et al. [42], oxygen and water inhibit the free-radical polymerization reaction and the complete curing of the resins. In this work, emulsified AESO was cured, probably not completely, in aqueous media. Thus, the exothermic peak in DSC curves may be associated with the free-radical polymerization. Indeed, this peak does not appear in the AESO mixture curve tested without the addition of a catalyst on Figure 6a. The increase in temperature promoted the decomposition of the initiator CHP, generating more free-radicals to complete the polymerization. Solutions to achieve full polymerization will be reported in forthcoming work.

Further, the degradation of the composite network structure constitutes the second endothermic transition at higher temperatures. The beginning of the structural disruption is defined as the temperature where $10 \mathrm{wt} \%$ of the mass is lost. It was observed that $\mathrm{T}_{10 \mathrm{wt}} \%$ for $\mathrm{BC}\left(326.4^{\circ} \mathrm{C}\right)$ was higher than $\mathrm{T}_{10 \mathrm{wt} \%}$ for all composites. Therefore, it can be inferred that native $\mathrm{BC}$ is more thermally stable than the polymeric composites.

The composites show less pronounced peaks with the main mass loss step, corresponding to the higher percentage of mass loss, observed in a broader temperature range. The $\mathrm{T}_{\mathrm{dmax}}$ decreases in the order $\mathrm{BC}>\mathrm{BC} / \mathrm{AESO}>\mathrm{BC} / \mathrm{AESO} / \mathrm{PEG}>\mathrm{BC} / \mathrm{AESO} / \mathrm{S}>\mathrm{BC} / \mathrm{AESO} / \mathrm{PEG} / \mathrm{S}>\mathrm{BC} / \mathrm{AESO} / \mathrm{PEG} / \mathrm{S} / \mathrm{H}>$ $\mathrm{BC} / \mathrm{AESO} / \mathrm{H}>\mathrm{BC} / \mathrm{AESO} / \mathrm{PEG} / \mathrm{H}$ and these results are in accordance with the DSC data. Although the composites are less stable thermally, they are stable up to $200^{\circ} \mathrm{C}$, so they can be applied in common leather applications.

\subsection{Mechanical Properties}

The average values and standard deviation of the tensile strength and elongation at break of the BC and BC-based composites are reported in Table 5, and the stress-strain curves are given in Figure 7. As deduced from Figure 7, neat BC displayed a rigid and brittle behavior, because of the extensive interactions between the polymer molecules that result in high tensile strength but low elongation at break. The incorporation of the plasticizers into polymers disrupts the intermolecular attractive forces between the main polymer chains and consequently increases the free volume and chain mobility, leading to an increase in extensibility $[50,74,75]$. Thus, when compared to the neat $\mathrm{BC}$ membrane, the incorporation of emulsified polymer mixtures leads to a reduction in the values of the tensile strength and an increase in the elongation at break. As observed by SEM (Figure 3), the polymers appeared to have completely covered the surface of the BC nanofibers, resulting in an increase in the composites' thickness (Table 3). As observed by DSC, AESO was not completely polymerized, thus it may have 
not fully acted as a reinforcing agent but also as a plasticizer, allowing higher mobility between the different layers of the $\mathrm{BC}$ membrane.

Table 5. Tensile strength and elongation at break of dried BC and BC composites.

\begin{tabular}{ccc}
\hline Sample & Tensile Strength $\mathbf{( M P a )}$ & Elongation at Break (\%) \\
\hline BC & $37.5 \pm 0.8$ & $3.6 \pm 0.6$ \\
BC/AESO & $17.3 \pm 0.7$ & $9.5 \pm 1.0$ \\
BC/AESO/PEG & $24.6 \pm 1.7$ & $13.9 \pm 0.8$ \\
BC/AESO/S & $22.6 \pm 3.3$ & $8.4 \pm 0.1$ \\
BC/AESO/PEG/S & $6.3 \pm 1.0$ & $9.4 \pm 2.3$ \\
BC/AESO/H & $35.9 \pm 3.0$ & $9.5 \pm 0.2$ \\
BC/AESO/PEG/H & $11.8 \pm 1.0$ & $12.9 \pm 2.0$ \\
BC/AESO/PEG/S/H & $6.9 \pm 0.2$ & $10.0 \pm 0.5$ \\
\hline
\end{tabular}

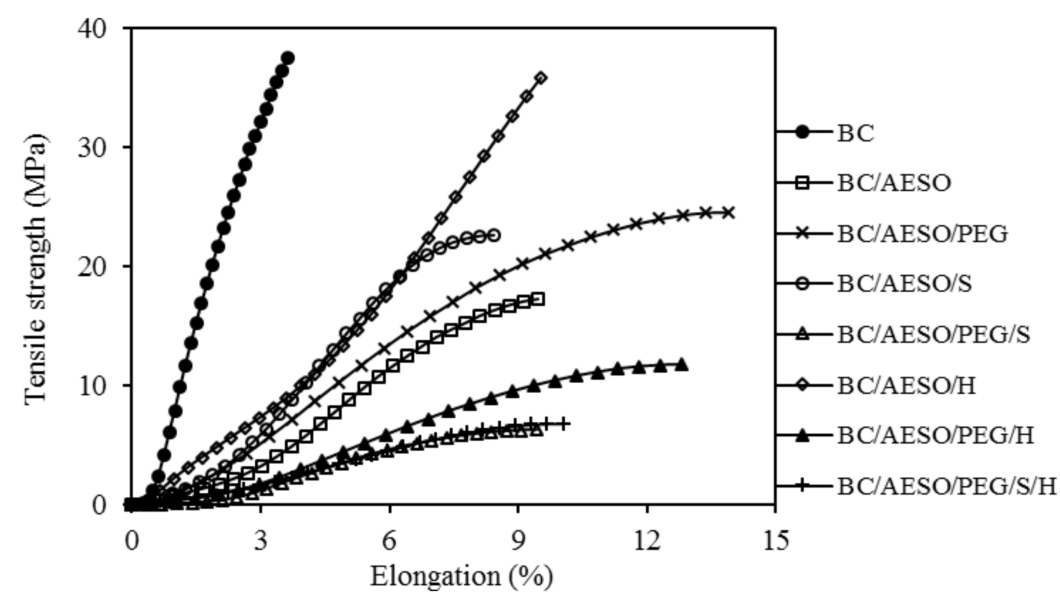

Figure 7. Stress strain curves of dried BC and BC composites.

The addition of either $\mathrm{S}$ or $\mathrm{H}$, to $\mathrm{BC} / \mathrm{AESO}$, improved the mechanical and elongation properties of the composites, as compared to BC/AESO. However, only for this composite (BC/AESO) the addition of PEG allowed increasing the mechanical properties. In general, it was observed that the addition of different polymers leads to a decrease in tensile strength and an increase in elongation at break. The incorporation of PEG resulted in a consistent and significant increase in the elongation at break values due to its plasticizing effect.

Overall, taking as reference the technical report ISO/TR20879 [76], with respect to the mechanical properties, most of the composites are suitable to be used in footwear. Regarding tensile strength values, $\mathrm{BC} / \mathrm{AESO} / \mathrm{PEG} / \mathrm{S}, \mathrm{BC} / \mathrm{AESO} / \mathrm{PEG} / \mathrm{H}$, and BC/AESO/PEG/S/H samples (more polymer content as shown in Table 3) were below the reference value (casual footwear: $>10 \mathrm{~N} / \mathrm{mm}$ ) $(\mathrm{MPa} \times$ Thickness), but in the case of the elongation at break, all samples presented values within the required reference values.

\section{Conclusions}

This work provided a straightforward method to prepare BC composites with high potential for applications as a replacement for leather. We have successfully prepared composites based on BC, emulsified AESO resin, PEG, and PDMS- and perfluorocarbon-based polymers through a simple strategy to enhance the flexibility and hydrophobicity of the BC.

Based on SEM observations and FTIR analysis, all the tested polymers penetrated well and uniformly into the BC matrix. The obtained composites showed hydrophobicity with the highest values of WCAs obtained for the composites with the perfluorocarbon-based product. Regarding the thermal and mechanical properties, it was found that the composites presented lower thermal stability 
and tensile strength, although they are stable up to $200{ }^{\circ} \mathrm{C}$ and most of the composites can be applied in uppers for shoes.

Further optimization of the process may improve its performance through improved control of the polymerization reaction. Hence, this work opens new perspectives for potential applications of BC in the footwear industry.

Author Contributions: M.F. wrote the manuscript, performed the main analysis and data collection. A.P.S. supervised the work. F.D. and M.G. supervised all works and revised and finalized the manuscript.

Funding: This study was supported by FEDER funding on the Programa Operacional Regional do Norte (NORTE2020) within the scope of the project NORTE-01-0247-FEDER-003435 ('BUILD-Bacterial cellulose Leather') and Bio-TecNorte operation NORTE-01-0145-FEDER-000004, FEDER funding on the Programa Operacional Factores de Competitividade-COMPETE within the scope of the project POCI-01-0145-FEDER-007136 and POCI-01- 0145-FEDER-006684, national funds through FCT-Foundation for Science and Technology within the scope of the project UID/CTM/00264/2019 and UID/BIO/04469/2013.

Acknowledgments: The authors thank Satisfibre, S.A. (Portugal) for the supply of bacterial cellulose.

Conflicts of Interest: The authors declare no conflict of interest.

\section{References}

1. FAO. World Statistical Compendium for Raw Hides and Skins, Leather and Leather Footwear 1999-2015; Food and Agriculture Organization of the United Nations (FAO): Rome, Italy, 2015; ISBN 978-92-5-109213-2.

2. Kanagaraj, J.; Senthilvelan, T.; Panda, R.C.; Kavitha, S. Eco-Friendly waste management strategies for greener environment towards sustainable development in leather industry: A comprehensive review. J. Clean. Prod. 2015, 89, 1-17. [CrossRef]

3. Wool, R. Composites Having Leather-Like Characteristics. U.S. Patent 2013/0337711 A1, 19 December 2013.

4. Black, M.; Casanova, M.; Rydin, S.; Scalet, B.M.; Roudier, S.; Sancho, L.D. Best Available Techniques (BAT)—Reference Document for the Tanning of Hides and Skins; European Union: Luxembourg, 2013; ISBN 978-92-79-32947-0.

5. Wang, J.; Tavakoli, J.; Tang, Y. Bacterial cellulose production, properties and applications with different culture methods-A review. Carbohydr. Polym. 2019, 219, 63-76. [CrossRef] [PubMed]

6. The Making of Nata de Coco Shoes. Available online: http://avrotor.blogspot.com/2017/12/the-making-ofnata-de-coco-shoes.html (accessed on 6 November 2017).

7. Grow Your Own Clothes. Available online: https://www.ted.com/talks/suzanne_lee_grow_your_own_ clothes/transcript (accessed on 2 November 2016).

8. Ng, F.M.C.; Wang, P.W. Natural self-grown fashion from bacterial cellulose: A paradigm shift design approach in fashion creation. Des. J. 2016, 19, 837-855. [CrossRef]

9. Ng, M.C.F.; Wang, W. A study of the receptivity to bacterial cellulosic pellicle for fashion. Res. J. Text. Appar. 2015, 19, 65-69. [CrossRef]

10. Yim, S.M.; Song, J.E.; Kim, H.R. Production and characterization of bacterial cellulose fabrics by nitrogen sources of tea and carbon sources of sugar. Process Biochem. 2017, 59, 26-36. [CrossRef]

11. Chan, C.K.; Shin, J.; Jiang, S.X.K. Development of tailor-shaped bacterial cellulose textile cultivation techniques for zero-waste design. Cloth. Text. Res. J. 2018, 36, 33-44. [CrossRef]

12. Fernandes, M.; Gama, M.; Dourado, F.; Souto, A.P. Development of novel bacterial cellulose composites for the textile and shoe industry. Microb. Biotechnol. 2019, 12, 650-661. [CrossRef]

13. Zhu, J.; Chandrashekhara, K.; Flanigan, V.; Kapila, S. Curing and mechanical characterization of a soy-based epoxy resin system. J. Appl. Polym. Sci. 2004, 91, 3513-3518. [CrossRef]

14. Kim, H.M.; Kim, H.R.; Hou, C.T.; Kim, B.S. Biodegradable photo-crosslinked thin polymer networks based on vegetable oil hydroxy fatty acids. J. Am. Oil Chem. Soc. 2010, 87, 1451-1459. [CrossRef]

15. Santiago, E.V.; López, S.H. Acrylated-Epoxidized soybean oil-based polymers and their use in the generation of electrically conductive polymer composites. In Soybean-Bio-Active Compounds; El-Shemy, H.A., Ed.; IntechOpen Limited: London, UK, 2013; pp. 231-263. ISBN 978-953-51-0977-8.

16. Saithai, P.; Lecomte, J.; Dubreucq, E.; Tanrattanakul, V. Effects of different epoxidation methods of soybean oil on the characteristics of acrylated epoxidized soybean oil-co-poly(methyl methacrylate) copolymer. Express Polym. Lett. 2013, 7, 910-924. [CrossRef] 
17. Khot, S.N.; Lascala, J.J.; Can, E.; Morye, S.S.; Williams, G.I.; Palmese, G.R.; Kusefoglu, S.H.; Wool, R.P. Development and application of triglyceride-based polymers and composites. J. Appl. Polym. Sci. 2001, 82, 703-723. [CrossRef]

18. Lu, J.; Wool, R.P. Development of new green SMC resins and nanocomposites from plant oils. In Proceedings of the 4th Anual SPE Automotive Composites Conference, Troy, MI, USA, 14-15 September 2004.

19. Grishchuk, S.; Karger-Kocsis, J. Hybrid thermosets from vinyl ester resin and acrylated epoxidized soybean oil (AESO). Express Polym. Lett. 2011, 5, 2-11. [CrossRef]

20. Senoz, E.; Stanzione, J.F.; Reno, K.H.; Wool, R.P.; Miller, M.E.N. Pyrolyzed chicken feather fibers for biobased composite reinforcement. J. Appl. Polym. Sci. 2013, 128, 983-989. [CrossRef]

21. Gandini, A.; Lacerda, T.M. From monomers to polymers from renewable resources: Recent advances. Prog. Polym. Sci. 2015, 48, 1-39. [CrossRef]

22. Liu, K.; Madbouly, S.A.; Kessler, M.R. Biorenewable thermosetting copolymer based on soybean oil and eugenol. Eur. Polym. J. 2015, 69, 16-28. [CrossRef]

23. Liu, W.; Fei, M.; Ban, Y.; Jia, A.; Qiu, R. Preparation and evaluation of green composites from microcrystalline cellulose and a soybean-oil derivative. Polymers 2017, 9, 541. [CrossRef]

24. Ramamoorthy, S.K.; Kundu, C.K.; Adekunle, K.; Bashir, T.; Skrifvars, M. Properties of green composites with regenerated cellulose fiber and soybean-based thermoset for technical applications. J. Reinf. Plast. Compos. 2014, 33, 193-201. [CrossRef]

25. Kocaman, S.; Karaman, M.; Gursoy, M.; Ahmetli, G. Chemical and plasma surface modification of lignocellulose coconut waste for the preparation of advanced biobased composite materials. Carbohydr. Polym. 2017, 159, 48-57. [CrossRef]

26. Ramamoorthy, S.K.; Skrifvars, M.; Alagar, R.; Akhtar, N. End-Of-Life textiles as reinforcements in biocomposites. J. Polym. Environ. 2018, 26, 487-498. [CrossRef]

27. Temmink, R.; Baghaei, B.; Skrifvars, M. Development of biocomposites from denim waste and thermoset bio-resins for structural applications. Compos. Part A Appl. Sci. Manuf. 2018, 106, 59-69. [CrossRef]

28. Lee, T.S.; Choi, H.Y.; Choi, H.N.; Lee, K.-Y.; Kim, S.-H.; Lee, S.G.; Yong, D.K. Effect of surface treatment of ramie fiber on the interfacial adhesion of ramie/acetylated epoxidized soybean oil (AESO) green composite. J. Adhes. Sci. Technol. 2013, 27, 1335-1347. [CrossRef]

29. Liu, W.; Fei, M.; Ban, Y.; Jia, A.; Qiu, R.; Qiu, J. Concurrent improvements in crosslinking degree and interfacial adhesion of hemp fibers reinforced acrylated epoxidized soybean oil composites. Compos. Sci. Technol. 2018, 160, 60-68. [CrossRef]

30. Akesson, D.; Skrifvars, M.; Walkenström, P. Preparation of thermoset composites from natural fibres and acrylate modified soybean oil resins. J. Appl. Polym. Sci. 2009, 114, 2502-2508. [CrossRef]

31. Nunez, F.U.; Santiago, E.V.; Lopez, S.H. Structural, thermal and morphological characterization of UV-graft polymerization of acrylated-epoxidized soybean oil onto goat leather. Chem. Chem. Technol. 2008, 2, 191-197.

32. Cao, H.; Wool, R.; Sidoriak, E.; Dan, Q. Evaluating mechanical properties of environmentally friendly leather substitute (eco-leather). In Proceedings of the International Textile and Apparel Association (ITAA) Annual Conference Proceedings, New Orleans, LA, USA, 15-18 October 2013.

33. Cao, H.; Wool, R.R.P.; Bonanno, P.; Dan, Q.; Kramer, J.; Lipschitz, S. Development and evaluation of apparel and footwear made from renewable bio-based materials. Int. J. Fash. Des. Technol. Educ. 2014, 7, 21-30. [CrossRef]

34. Blaker, J.J.; Lee, K.Y.; Li, X.; Menner, A.; Bismarck, A. Renewable nanocomposite polymer foams synthesized from Pickering emulsion templates. Green Chem. 2009, 11, 1321-1326. [CrossRef]

35. Sousa, A.F.; Ferreira, S.; Lopez, A.; Borges, I.; Pinto, R.J.B.; Silvestre, A.J.D.; Freire, C.S.R. Thermosetting AESO-bacterial cellulose nanocomposite foams with tailored mechanical properties obtained by Pickering emulsion templating. Polymer 2017, 118, 127-134. [CrossRef]

36. Lee, K.-Y.; Wong, L.L.C.; Blaker, J.J.; Hodgkinson, J.M.; Bismarck, A. Bio-Based macroporous polymer nanocomposites made by mechanical frothing of acrylated epoxidised soybean oil. Green Chem. 2011, 13, 3117-3123. [CrossRef]

37. Retegi, A.; Algar, I.; Martin, L.; Altuna, F.; Stefani, P.; Zuluaga, R.; Gañán, P.; Mondragon, I. Sustainable optically transparent composites based on epoxidized soy-bean oil (ESO) matrix and high contents of bacterial cellulose (BC). Cellulose 2012, 19, 103-109. [CrossRef] 
38. Cousinet, S.; Ghadban, A.; Fleury, E.; Lortie, F.; Pascault, J.P.; Portinha, D. Toward replacement of styrene by bio-based methacrylates in unsaturated polyester resins. Eur. Polym. J. 2015, 67, 539-550. [CrossRef]

39. Wei, G.; Xu, H.; Chen, L.; Li, Z.; Liu, R. Isosorbide-Based high performance UV-curable reactive diluents. Prog. Org. Coat. 2019, 126, 162-167. [CrossRef]

40. ICI Americas Inc. Meaning of HLB: Advantages and limitations. In The HLB System: A Time-Saving Guide to Emulsifier Selection; ICI Americas Inc.: Wilmington, DE, USA, 1980; pp. 1-4.

41. Alany, R.G.; Rades, T.; Agatonovic-Kustrin, S.; Davies, N.M.; Tucker, I.G. Effects of alcohols and diols on the phase behaviour of quaternary systems. Int. J. Pharm. 2000, 196, 141-145. [CrossRef]

42. Dweib, M.A.; Hu, B.; Shenton, H.W.; Wool, R.P. Bio-Based composite roof structure: Manufacturing and processing issues. Compos. Struct. 2006, 74, 379-388. [CrossRef]

43. De Lima, G.F.; De Souza, A.G.; Rosa, D.S. Effect of adsorption of polyethylene glycol (PEG), in aqueous media, to improve cellulose nanostructures stability. J. Mol. Liq. 2018, 268, 415-424. [CrossRef]

44. Khalaf, A.I.; El Nashar, D.E.; Helaly, F.M.; Soliman, A. Evaluation of controlled release PVC/PEG polymeric films containing 5-fluorouracil for long-term antitumor. Polym. Bull. 2019, 76, 3555-3568. [CrossRef]

45. Wu, S. Calculation of interfacial tension in polymer systems. J. Polym. Sci. Part C Polym. Symp. 1971, 34, 19-30. [CrossRef]

46. Oliveira, F.R.; Fernandes, M.; Carneiro, N.; Pedro Souto, A. Functionalization of wool fabric with phase-change materials microcapsules after plasma surface modification. J. Appl. Polym. Sci. 2013, 128. [CrossRef]

47. ISO. ISO 17706:2003 Footwear-Test Methods for Uppers-Tensile Strength and Elongation; ISO: Geneva, Switzerland, 2003.

48. Khan, S.; Ul-islam, M.; Ullah, M.W.; Israr, M.; Jang, J.H.; Park, J.K. Nano-Gold assisted highly conducting and biocompatible bacterial cellulose-PEDOT:PSS films for biology-device interface applications. Int. J. Biol. Macromol. 2018, 107, 865-873. [CrossRef]

49. He, J.; Zhao, H.; Li, X.; Su, D.; Zhang, F.; Ji, H.; Liu, R. Superelastic and superhydrophobic bacterial cellulose/silica aerogels with hierarchical cellular structure for oil absorption and recovery. J. Hazard. Mater. 2018, 346, 199-207. [CrossRef]

50. Sun, Y.; Meng, C.; Zheng, Y.; Wang, Y.; Qiao, K.; Yue, L.; Xie, Y.; He, W. The effects of two biocompatible plasticizers on the performance of dry bacterial cellulose membrane: A comparative study. Cellulose 2018, 25, 5893-5908. [CrossRef]

51. Alonso, E.; Faria, M.; Faranak, M.; Resnik, M.; Ferreira, A.; Cordeiro, N. Conductive bacterial cellulose-polyaniline blends: Influence of the matrix and synthesis conditions. Carbohydr. Polym. 2018, 183, 254-262. [CrossRef] [PubMed]

52. Mandal, M.; Maji, T.K. Comparative study on the properties of wood polymer composites based on different modified soybean oils. J. Wood Chem. Technol. 2017, 37, 124-135. [CrossRef]

53. Lu, P.; Xiao, H.; Zhang, W.; Gong, G. Reactive coating of soybean oil-based polymer on nanofibrillated cellulose film for water vapor barrier packaging. Carbohydr. Polym. 2014, 111, 524-529. [CrossRef] [PubMed]

54. Araki, J.; Mishima, S. Steric stabilization of "charge-free" cellulose nanowhiskers by grafting of poly(ethylene glycol). Molecules 2015, 20, 169-184. [CrossRef] [PubMed]

55. Zhang, W.; Kalulu, M.; Wang, X.-H.; Xia, X.-K.; Han, X.-L.; Jiang, Y. Reverse hydrophobic PDMS surface to hydrophilic by 1-step hydrolysis reaction. Polym. Adv. Technol. 2018, 29, 1-7. [CrossRef]

56. Wu, X.; Li, J.; Li, G.; Ling, L.; Zhang, G.; Sun, R.; Wong, C.-P. Heat-Triggered poly(siloxane-urethane)s based on disulfide bonds for self-healing application. J. Appl. Polym. Sci. 2018, 135, 46532. [CrossRef]

57. Mohd, N.H.; Farahein, N.; Ismail, H.; Zahari, J.I.; Farahhanim, W.; Kargarzadeh, H.; Ramli, S.; Ahmad, I.; Yarmo, M.A.; Othaman, R. Effect of aminosilane modification on nanocrystalline cellulose properties. J. Nanomater. 2016, 2016. [CrossRef]

58. Zargar, R.; Nourmohammadi, J.; Amosbediny, G. Preparation, characterization, and silanization of 3D microporous PDMS structure with properly sized pores for endothelial cell culture. Biotechnol. Appl. Biochem. 2016, 63, 190-199. [CrossRef]

59. Saini, S.; Belgacem, M.N.; Salon, M.-C.B.; Bras, J. Non leaching biomimetic antimicrobial surfaces via surface functionalisation of cellulose nanofibers with aminosilane. Cellulose 2016, 23, 795-810. [CrossRef]

60. Shao, W.; Wu, J.; Liu, H.; Ye, S.; Jiang, L.; Liu, X. Novel bioactive surface functionalization of bacterial cellulose membrane. Carbohydr. Polym. 2017, 178, 270-276. [CrossRef] 
61. Mukherjee, T.; Rimal, S.; Koskey, S.; Chyan, O.; Singh, K.J.; Myers, A.M. Bonding structure of model fluorocarbon polymer residue determined by functional group specific chemical derivatization. ECS Solid State Lett. 2013, 2, 11-14. [CrossRef]

62. Li, C.; Xiao, H.; Wang, X.; Zhao, T. Development of green waterborne UV-curable vegetable oil-based urethane acrylate pigment prints adhesive: Preparation and application. J. Clean. Prod. 2018, 180, 272-279. [CrossRef]

63. Xu, X.; Jagota, A.; Paretkar, D.; Hui, C. Surface tension measurement from the indentation of clamped thin films. Soft Matter 2016, 12, 5121-5126. [CrossRef] [PubMed]

64. Tian, Y.; Ina, M.; Cao, Z.; Sheiko, S.S.; Dobrynin, A.V. How to measure work of adhesion and surface tension of soft polymeric materials. Macromolecules 2018, 51, 4059-4067. [CrossRef]

65. Milionis, A.; Bayer, I.S.; Loth, E. Recent advances in oil-repellent surfaces. Int. Mater. Rev. 2016, 61, $101-106$. [CrossRef]

66. Kondo, T.; Sawatari, C.; Manley, R.S.J.; Gray, D.G. Characterization of hydrogen bonding in cellulose-synthetic polymer blend systems with regioselectively substituted methylcellulose. Macromolecules 1994, 27, 210-215. [CrossRef]

67. Barud, H.S.; Souza, J.L.; Santos, D.B.; Crespi, M.S.; Ribeiro, C.A.; Messaddeq, Y.; Ribeiro, S.J.L. Bacterial cellulose/poly (3-hydroxybutyrate) composite membranes. Carbohydr. Polym. 2011, 83, 1279-1284. [CrossRef]

68. Frone, A.N.; Panaitescu, D.M.; Chiulan, I.; Nicolae, C.A.; Casarica, A.; Gabor, A.R.; Trusca, R.; Damian, C.M.; Purcar, V.; Alexandrescu, E.; et al. Surface treatment of bacterial cellulose in mild, eco-friendly conditions. Coatings 2018, 8, 221. [CrossRef]

69. Hu, Y.; Sheng, J.; Yan, Z.; Ke, Q. Completely amorphous cellulose biosynthesized in agitated culture at low temperature. Int. J. Biol. Macromol. 2018, 117, 967-973. [CrossRef]

70. Liu, C.; Liu, Z.; Tisserat, B.H.; Wang, R.; Schuman, T.P.; Zhou, Y.; Hu, L. Microwave-Assisted maleation of tung oil for bio-based products with versatile applications. Ind. Crop. Prod. 2015, 71, 185-196. [CrossRef]

71. Liu, F.; Miao, L.; Wang, Y.; Xue, X.; Yang, H. Progress in organic coatings green fabrication of ultraviolet curable epoxy acrylate-silica hybrid coatings. Prog. Org. Coat. 2017, 109, 38-44. [CrossRef]

72. Zhang, C.; Yan, M.; Cochran, E.W.; Kessler, M.R. Biorenewable polymers based on acrylated epoxidized soybean oil and methacrylated vanillin. Mater. Today Commun. 2015, 5, 18-22. [CrossRef]

73. Liu, W.; Xie, T.; Qiu, R. Biobased thermosets prepared from rigid isosorbide and flexible soybean oil derivatives. ACS Sustain. Chem. Eng. 2017, 5, 774-783. [CrossRef]

74. Salarbashi, D.; Bazeli, J.; Tafaghodi, M. Environment-Friendly green composites based on soluble soybean polysaccharide: A review. Int. J. Biol. Macromol. 2019, 122, 216-223. [CrossRef] [PubMed]

75. Boon, D.; Lim, K.; Gong, H. Highly stretchable and transparent films based on cellulose. Carbohydr. Polym. 2018, 201, 446-453.

76. ISO. ISO/TR 20879:2007 Footwear_Performance Requirements for Components for Footwear_Uppers; ISO: Geneva, Switzerland, 2007.

(C) 2019 by the authors. Licensee MDPI, Basel, Switzerland. This article is an open access article distributed under the terms and conditions of the Creative Commons Attribution (CC BY) license (http://creativecommons.org/licenses/by/4.0/). 